\title{
Genetic variations among Indonesian native cattle breeds based on polymorphisms analysis in the growth hormone loci and mitochondrial DNA
}

\author{
SUTARNO \\ Department of Biology, Faculty of Mathematics and Natural Sciences, Sebelas Maret University, Jl. Ir. Sutami 36A Surakarta 57126, Tel./fax. +62-271- \\ 663375, ”email: nnsutarno@yahoo.com
}

Manuscript received: 20 October 2009. Revision accepted: 26 December 2009.

\begin{abstract}
Sutarno (2010) Genetic variations among Indonesian native cattle breeds based on polymorphisms analysis in the growth hormone loci and mitochondrial DNA. Biodiversitas 11: 1-5. Genetic variation within breeds is important and its study has become a subject of interest in livestock species, as it has many applications in animal breeding and genetics, such as the identification of animals and parentage testing, gene mapping and identifying markers for performance traits. Two loci of bovine growth hormone genes, and two regions of mitochondrial DNA, D-loop and ND-5 were characterized using polymerase chain reaction - restriction fragment length polymorphism (PCR-RFLP) involving 120 Indonesian native cattle of Bali, Madura, PO and West Sumatra breeds. The results indicated that sequence variations were detected both in the growth hormone loci and mitochondrial DNA.
\end{abstract}

Key words: marker assisted selection, local Indonesian cattle, PCR-RFLP, GH gene, mtDNA.

\section{INTRODUCTION}

Advanced techniques of molecular biology have provided the opportunity to study genetic diversity within and among breeds at gene level. Candidate QTLs, such as the growth hormone gene, BoLA gene and casein gene have been extensively studied. Variation in the growth hormone gene has been reported in many cattle breeds (Lucy et al. 1993; Sutarno 1998, 2001; Beauchemin et al. 2006). Schlee et al. (1994b) reported different concentrations of plasma growth hormone related to different growth hormone genotypes of cattle. Mitochondrial DNA polymorphism has been reported within and between breeds of mostly European cattle (Ron et al. 1990; Sutarno and Lymbery 1997). Loftus et al. (1994) used mtDNA polymorphisms to study the phylogeny of different breeds of cattle from Europe, Asia and Africa, however there was not any report for Indonesian native cattle.

In cattle, the growth hormone gene (bovine somatotropin gene) has been cloned and completely sequenced (Woychik et al. 1982). It is 1793 bp long, consisting of five exons separated by four intervening sequences (introns) of 248 bp (A), 227 bp (B), 227 bp (C) and 274 bp (D) in length (Gordon et al. 1983). The bovine growth hormone gene has been assigned to chromosome region 19q26-qtr (Hediger et al. 1990).

Variation in the growth hormone gene has been reported in many livestock animals, including cattle (Sutarno 2004, 2005; Beauchemin et al. 2006; Thomas et al. 2006), pigs (Nielsen and Larsen 1991), and sheep (Gootwine et al. 1990). Harvey (1995) suggested that deletions result in growth hormone deficiency or the synthesis of defective growth hormone variants. PCR procedures followed by restriction endonuclease digestions were recently used for typing further growth hormone gene variations, such as a MspI polymorphism (Mitra et al. 1995; Sutarno 2004), and an AluI polymorphism (Mitra et al. 1995) in the bovine growth hormone gene.

Mammalian mtDNA is a double stranded, covalently closed-circular molecule of approximately 16500 nucleotides located within the inner mitochondrial membrane (Shoffner and Wallace 1990). Bovine mitochondrial DNA has been completely sequenced and is $16.338 \mathrm{~kb}$ long (Anderson et al. 1982). Mammalian mitochondria carry multiple copies of mtDNA which are replicated and expressed in the mitochondria, and inherited maternally (Wallace 1993). The mitochondrial genome contains genes that encode 13 polypeptides involved in the oxidative phosphorylation (OXPHOS) system, together with the $12 \mathrm{~S}$ and $16 \mathrm{~S}$ ribosomal RNAs and the 22 mitochondrial transfer RNAs necessary for mRNA expression. Loftus et al. (1994) described the organization of bovine mitochondrial DNA with locations of known restriction sites.

Because of their involvement in the energy generating pathway (ATP synthesis), mitochondria and mitochondrial DNA are found in all animal species. Enzymes encoded by mtDNA participate in mitochondrial oxidative phosphorylation of ADP to ATP. In this process, both nuclear and mitochondrial DNA are required to cooperatively perform the respiratory function (Shadel and Clayton 1997).

Variation of mitochondrial DNA has also been demonstrated within species. Brown and Vinograd (1974) were the first to demonstrate intraspecific mtDNA variation using restriction endonuclease analysis. This technique was then applied in pedigree analysis, the estimation of 
evolutionary relationships, determination of mtDNA involvement in disease, intraspecific migration rates, and involvement of mtDNA in affecting production traits.

The aims of the study were therefore to investigate polymorphisms in the growth hormone gene and mitochondrial DNA of many Indonesian native cattle breeds such as Bali, Madura, PO and West Sumatra coastal area

\section{MATERIALS AND METHODS}

\section{Experimental cattle}

The cattle used in this study were of Indonesian local cattle comprising of 4 different breeds, Bali, Madura, Ongole derived (PO) and Western Sumatra coastal area cattles. The samples were consist of 30 cattle of each breed.

\section{Blood collection}

Blood was collected by venepuncture into a $10 \mathrm{~mL}$ Venoject tube containing heparin as anticoagulant. White blood cells were then isolated from the remaining $10 \mathrm{~mL}$ of blood.

\section{Isolation of white blood cells}

Whole blood was dispensed into centrifuge tubes, and then spun at about $1500 \mathrm{~g}$ for $15-20$ minutes. The buffy coat was removed with a pipette, transferred to $10 \mathrm{~mL}$ centrifuge tubes, topped up with TE-1 buffer and centrifuged at $2000 \mathrm{~g}$ for $10-15$ minutes. The pellet was resuspended in $1 \mathrm{~mL}$ of TE-2 buffer, transferred to $1 \mathrm{~mL}$ Nunc storage tube, and frozen at $-84^{\circ} \mathrm{C}$.

\section{Extraction of genomic DNA and mtDNA from white blood cells}

The genomic DNA was extracted using Wizard genomic DNA purification system from Promega as instructed by the manufacturer, while the mitochondrial DNA was extracted using the Wizard Minipreps DNA Purification System (Promega, Madison, USA).

\section{Genotyping}

Polymerase chain reaction and restriction fragment length polymorphisms (PCR-RFLP) were used to detect polymorphisms in the growth hormone gene and mitochondrial DNA.

\section{PCR amplification of growth hormone gene}

Growth hormone locus 1 (GHL1), a 223 bp region spanning intron IV and exon $\mathrm{V}$, and growth hormone locus 2 (GH-L2), a 329 bp region spanning exon III and exon IV of the growth hormone gene were amplified by PCR using primers GH1/GH2 and GH5/GH6 respectively.

The primers used to amplify these fragments were:

GH1: 5'-GCTGCTCCTGAGGGCCCTTCG-3'

GH2: 5'-GCGGCGGCACTTCATGACCCT-3'

GH5: 5'-CCCACGGGCAAGAATGAGGC-3'

GH6: 5'-TGAGGAACTGCAGGGGCCCA-3'

\section{PCR amplification of D-loop and ND-5 of mtDNA}

The non-coding D-loop region and part of the gene coding for NADH dehydrogenase sub-unit 5 (ND-5) were amplified by PCR, using primers D-L/D-R and ND-L/NDR (Suzuki et al. 1993 cit. Sutarno, 2008):
D-loop primers:

D-L: 5'-TAG TGC TAATACCAACGGCC-3'

D-R: 5'-AGGCAT TTTCAG TGCCTTGC-3'

ND-5 primers:

ND-L: 5'-ATCCGTTGGTCTTAGGAACC-3'

ND-R: 5'-TTGCGGTTACAAGGATGAGC-3'

All amplification reactions were performed in a $25 \mathrm{uL}$ reaction mix consisting of $200 \mathrm{ng}$ of template DNA, 0.15 $\mathrm{uM}$ each of the oligonucleotide primers $200 \mathrm{uM}$ each dNTPs, $2 \mathrm{mM} \mathrm{MgCl} 2$, 10x buffer and 1.5 units Taq DNA polymerase (Promega) in $0.2 \mathrm{~mL}$ PCR reaction tube.

\section{RFLP Analysis}

The PCR products were used directly in restriction enzyme digestion reactions. Amplified DNA of growth hormone locus 1 was digested with restriction endonuclease $A l u \mathrm{I}$ (Promega) to identify the AluI site polymorphism, and amplified DNA of growth hormone locus 2 was digested with restriction endonuclease $M s p$ I (Promega) to identify the MspI site polymorphism. The Amplified products of D-loop and ND-5 fragments were digested using restriction enzymes of $S s p$ I and HindIII respectively.

Electrophoresis was performed using horizontal gels, in electrophoretic cells (Bio-Rad, Richmond, U.S.A) for 90 minutes at 55 volts. Ethidium bromide was included in the gel at a final concentration of $0.12 \mu \mathrm{g} / \mathrm{mL}$. After electrophoresis, DNA was visualized under UV-illumination and photographed using Polaroid type 57 film with a red filter.

\section{RESULTS AND DISCUSSION}

\section{Results}

The $223 \mathrm{bp}$ fragment of locus 1 spanning intron IV and exon $\mathrm{V}$ of the growth hormone gene, amplified using primers GH-1 and GH-2, and the 329 bp locus 2 spanning exon III and exon IV of the growth hormone gene were amplified using primers GH5 and GH6. An example of gel photograph showing the polymorphisms of the amplified product cut by $A l u \mathrm{I}$ restriction enzyme were shown in Figure 1.

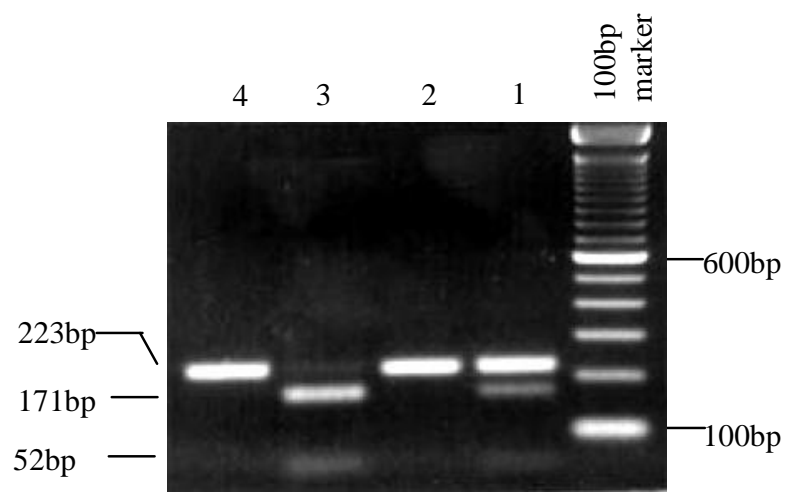

Figure 1. Gel photographs showing growth hormone gene polymorphisms detected by PCR-RFLP using AluI in locus 1 fragment. Lane $1=\mathrm{LV}$, Lane $2=\mathrm{VV}$, Lane $3=\mathrm{LL}$, and lane $4=$ Uncut. 
The patterns of restriction enzymes digestion to those loci were described in Table 1 for AluI and MspI in the growth hormone loci, and the D-loop and ND-5 digestion were presented in Table 2. The frequencies of allele and genotype resulted based on the PCR-RFLP analysis at growth hormone loci by employing AluI and $M s p \mathrm{I}$ restriction enzymes were shown in Table 3 and 4 subsequently.

Table 1. Restriction sites for AluI in the 223bp locus 1 (GH L1) fragment, and for $M s p I$ in the 453 bp locus 2 (GH L2) fragment of the growth hormone gene.

\begin{tabular}{llcl}
\hline Enzyme & \multicolumn{1}{c}{ Allele } & $\begin{array}{c}\text { No of restriction } \\
\text { sites }\end{array}$ & \multicolumn{1}{c}{$\begin{array}{c}\text { Fragment size } \\
\text { (bp) }\end{array}$} \\
\hline Alu I & L & 1 & 171,52 \\
& V & 0 & 223 \\
\multirow{2}{*}{ Msp I } & $M s p$ I + & 1 & 224,105 \\
& $M s p$ I & 0 & 329 \\
\hline
\end{tabular}

Table 2. Restriction sites for $S s p$ I in D-loop, and HindIII for ND5 regions of mitochondrial DNA.

\begin{tabular}{llll}
\hline Enzymes & Alleles & Number of sites & Fragment size (kb) \\
\hline D-loop & & & $0.85,0.29$ \\
SspI & A & 1 & $0.66,0.29,0.15$ \\
& B & 2 & \\
ND-5 & & & $0.33,0.13$ \\
HindIII & A & 1 & 0.46 \\
& B & 0 & \\
\hline
\end{tabular}

Table 3. Alleles frequency of $M s p \mathrm{I}(+), M s p \mathrm{I}(-), \mathrm{L}, \mathrm{V}$ from PO, Bali, Madura, and Pesisir cattle population

\begin{tabular}{lcccc}
\hline Breeds & MspI (+) & Msp I (-) & L & V \\
\hline PO & 0.74 & 0.26 & 0.9 & 0.1 \\
Bali & 0.36 & 0.54 & 0.8 & 0.2 \\
Madura & 0.28 & 0.72 & 0.9 & 0.1 \\
Pesisir & 0.38 & 0.52 & 0.8 & 0.2 \\
\hline
\end{tabular}

Table 4. Genotype frequency of PO, Bali, Madura, and Pesisir cattle population

\begin{tabular}{lcccccl}
\hline Breeds & $\begin{array}{c}\text { MspI } \\
(++)\end{array}$ & $\begin{array}{c}\text { MspI } \\
(--)\end{array}$ & $\begin{array}{c}\text { MspI } \\
(+-)\end{array}$ & LL & VV & LV \\
\hline PO & 0.50 & 0.07 & 0.43 & 1.00 & 0 & 0 \\
Bali & 0.53 & 0.07 & 0.40 & 0.94 & 0 & 0.06 \\
Madura & 0.40 & 0.03 & 0.57 & 1.00 & 0 & 0 \\
Pesisir & 0.47 & 0.03 & 0.50 & 0.74 & 0.06 & 0.20 \\
\hline
\end{tabular}

\section{Discussion}

As demonstrated in this study, recent developments in molecular techniques have resulted in an abundance of data on genetic polymorphisms from DNA analysis. These data will provide us with a better understanding of the nature of genetic variation within and between cattle breeds. PCRRFLP analysis can detect the same type of polymorphisms as traditional RFLP analysis, but without the need for Southern blotting (Cushwa and Medrano 1996), thus decreasing the time taken and increasing sensitivity. This method is therefore very useful for the study of genetic variation.

Genetic variation within breeds is important and its study has become a subject of interest in livestock species, as it has many applications in animal breeding and genetics, such as the identification of animals and parentage testing, gene mapping and identifying markers for performance traits. Since all phenotypic characters are influenced by the genetic information carried by DNA, DNA variation may be correlated with variation in performance traits. This idea is the basis for marker assisted selection (MAS), which has aroused much interest in recent years (Soller 1994; Schwerin et al. 1995). Genetic variation, measured at the DNA level, can also be used as a check on the level of genetic variation in quantitative traits maintained within breeds.

The genotype frequencies of MspI (++), MspI (+-) and MspI (--) were relatively similar in the four breeds of the Indonesian cattle. However, the genotype frequencies of LL, VV and LV were quite different between breeds. The genotype of VV was not detected in PO, Bali and Madura cattle breeds, and very rare (0.06) in Pesisir cattle breed. The genotype LV was also not detected in PO and Madura cattle breeds, and quite rare (between 0.06 and 0.2 ) found in Bali and Pesisir cattle breeds. It thus both VV and LV genotypes were quite rare in Indonesian native cattle breeds. Increasing the number of sample for analysis in each breed possibly could reveal or increase the rare frequency of both genotypes.

The AluI and MspI restriction site polymorphisms in the locus 1 and locus 2 fragments of the growth hormone gene found in the study have also been previously reported in dairy cattle (Hoj et al. 1993a; Lucy et al. 1993), Bavarian Simmental (Schlee et al. 1994a), Indian cattle (Mitra et al. 1995) and Hereford and composite cattle (Sutarno 1998). Polymorphisms were found in the mitochondrial D-loop region with PstI and $S s p \mathrm{I}$, and in the mitochondrial ND-5 region using HindIII and SpeI. As previously reported by Sutarno and Lymbery (1997), the new polymorphisms in the D-loop by PCR-RFLP analysis using $S s p$ I and in the ND-5 region using SpeI were also found in the Indonesian local cattle. Compared to the standard bovine sequence of mitochondrial DNA (Anderson et al. 1982), these variant sequences have an extra AvaII and SspI site in the D-loop and have lost an SpeI site in mitochondrial ND-5. Sutarno and Lymbery (Sutarno and Lymbery 1997) suggested that the most likely scenarios for restriction site gains in the Dloop are a $\mathrm{T}$ to $\mathrm{C}$ transition at position 16273 to create a new AvaII site, and a $\mathrm{C}$ to $\mathrm{T}$ transition at position 245 to create a new SspI site. This was confirmed with the sequence data presented in by Sutarno (1998).

For conservation purposes, study of the genetic variation between livestock breeds is very important. Adaptation to their different environmental challenges may have resulted in a unique combination of alleles specific to certain breeds, and this would be difficult to recreate (Hall and Bradley 1995). Breeds which are very different to others may need to be conserved, since the genes and gene combinations that they carry may be useful to agriculture in the future. 
Bali cattle (Bos javanicus javanicus), more popularly called Banteng, have been domesticated largely in Indonesia, especially in Java, Bali, Sumbawa and Borneo. Cattle of this type superficially resemble Zebu, as they possess a hump, but the bone structure of the head is quite different. Copland (1996) suggested that Bali cattle are more similar to ancestral cattle than other modern types. According to the assessment done by AWCSG (Asian Wild Cattle Specialist Group) in 1995, Bos javanicus has been categorized as endangered, due to disease, hunting, hybridization or trade. Indeed, the introduction of modern cattle to Indonesia in the last few decades has partly caused a reduction in the diversity of Bali cattle. This is unfortunate because they are considered an original species with several economic advantages such as high fertility rate, adaptability and carcass percentage.

Another important application of genetic variation between breeds is to predict the crosses between breeds that will produce crossbreed offspring with maximum heterosis. Much more attention has been paid in recent years to the utilization of heterosis in beef cattle and other livestock species. However, because there are so many breeds that could be used for crossbreeding, it is impossible to experimentally cross and compare all breeds.

\section{CONCLUSION}

Based on these results, and previous studies, indicated that both of growth hormone gene and mitochondrial DNA are vary between breeds of Indonesian native cattle, and it is reasonable to presume that genetic variation in production traits is partly caused by variation in the genetic constitution of the genes such as growth hormone gene that coding for hormones and receptors in the growth hormone axis, and mitochondrial DNA that responsible for oxidative phosphorylation for energy production.

\section{REFERENCES}

Anderson S, De Bruijn MHL, Coulson AR, Eperon IC, Sanger, F, Young, IG (1982) Complete sequence on bovine mitochondrial DNA: conserved features of the mammalian mitochondrial genome. J Mol Biol 156: 683-717.

Beauchemin VR, Thomas MG, Franke DE, Silver GA (2006) Evaluation of DNA polymorphisms involving growth hormone relative to growth and carcaas characteristics in Brahman steers. Genet Mol Res 5 (3): 438-447.

Beckmann JS, Kashi Y, Hallerman EM, Nave A, Soller M (1986) Restriction fragment length polymorphism among Israeli HolsteinFriesian dairy bulls. Anim Genet 17: 25-38.

Copland JW (1996) Bali cattle: origins in Indonesia. ACIAR Proceedings 75: 29-33.

Corden J, Wasylyk B, Buchwalder A, Sassone-Corsi P, Kedinger C, Chambon P (1980) Promoter sequences of eukaryotic protein-coding genes. Science 209: 1406-1414.

Cowan CM, Dentine MR, Ax RL, Schuler LA (1989) Restriction fragment length polymorphisms associated with growth hormone and prolactin genes in Holstein bulls: Evidence for a novel growth hormone allele. Anim Genet 20: 25-38.

Cushwa WT, Medrano JF (1996) Applications of the random amplified polymorphic DNA (RAPD) assay for genetic analysis of livestock species. Anim Biotechnol 7: 11-31.
Gootwine E, Valinsky A, Shani M (1990) Restriction fragment length polymorphism at the growth hormone gene in sheep, goats and cattle. Proceedings of The 4th World Congress on Genetics Applied to Livestock Production XIII, Edinburgh 13: 83-85.

Gordon DF, Quick DP, Erwin CR, Donelson JE, Maure RA (1983) Nucleotide sequence of the bovine growth hormone chromosomal gene. Mol Cell Endocrinol 33: 81-95.

Hall SJG, Bradley DG (1995) Conserving livestock breed biodiversity [Review]. Trends Ecol Evolut 10: 267-270.

Hallerman EM, Nave A, Kashi Y, Halzer Z, Soller M, Beckmann JS (1987) Restriction fragment length polymorphisms in dairy and beef cattle at the growth hormone and prolactin loci. Anim Genet 18: 213222.

Harvey S (1995) Growth hormone synthesis. In: Harvey S, Scanes CG, Daughaday WH (ed.) Growth hormone. CRC Press, Boca Raton.

Hediger R, Johnson SE, Barendse W, Drinkwater RD, Moore SS, Hetzel J (1990) Assignment of the growth hormone gene locus to 19q26-qter in cattle and to 11q25-qter in sheep by in situ hybridization. Genomics 8: 171-174

Hilbert P, Marcotte A, Schwers A, Hanset R, Vassart G, Georges M (1989) Analysis of genetic variation in the Belgian Blue cattle breed using DNA sequence polymorphism at the growth hormone low density lipoprotein receptor, a-subunit of glycoprotein hormones and thyroglobulin loci. Anim Genet 20: 383-394.

Hoj S, Fredholm M, Larsen NJ, Nielsen VH (1993) Growth hormone gene polymorphism associated with selection for milk fat production in lines of cattle. Anim Genet 24: 91-96.

Loftus RT, Machugh DE, Ngere LO, Balain DS, Badi AM, et al. (1994) Mitochondrial genetic variation in European, African and Indian cattle populations. Anim Genet 25: 265-271.

Lucy MC, Hauser SD, Eppard PJ, Krivi GG, Clark JH, et al. (1993) Variants of somatotropin in cattle - gene frequencies in major dairy breeds and associated milk production. Domest Anim Endocrinol 10: 325-333.

Mitra A, Schlee P, Balakrishnan CR, Pirchner F (1995) Polymorphisms at growth-hormone and prolactin loci in Indian cattle and buffalo. J Anim Breed Genet 112: 71-74.

Nielsen VH, Larsen NJ (1991) Restriction fragment length polymorphisms at the growth hormone gene in pigs. Animal genetics 22 (3): 291-294.

Schlee P, Graml R, Rottmann O, Pirchner F (1994a) Influence of growth hormone genotypes on breeding values of simmental bulls. J Anim Breed Genet 111: 253-256.

Schlee P, Graml R, Schallenberger E, Schams D, Rottmann O, et al. (1994b) Growth hormone and insulin like growth factor I concentrations in bulls of various growth hormone genotypes. Theor Appl Genet 88: 497-500.

Schwerin M, Brockmann G, Vanselow J, Seyfert HM (1995) Perspectives of molecular genome analysis in livestock improvement. Arch Anim Breed 38: 21-31.

Shadel GS, Clayton DA (1997) Mitochondrial DNA maintenance in vertebrates. Annu Rev Biochem 66: 409-435

Shoffner JM, Wallace DC (1990) Oxidative phosphorylation diseases: disorders of two genomes. Adv Hum Genet 19: 267-380.

Soller M (1994) Marker assisted selection - an overview. Anim Biotechnol 5: 193-207.

Sutarno (1998) Candidate gene marker for production traits in beef cattle. In: Vet Biology. Murdoch University, Perth.

Sutarno, Lymbery AJ (1997) New RFLPs in the mitochondrial genome of cattle. Anim Genet 28: 240-241

Suzuki R, Kemp SJ, Teale AJ (1993) Polymerase chain reaction analysis of mitochondrial DNA polymorphism in Ndama and Zebu cattle. Anim Genet 24: 339-343.

Thomas MG, Silver GA, Enns RM (2006) Relationships of DNA polymorphisms in growth hormone $(\mathrm{GH})$ to growth and carcass traits of Brangus. Bull Int Plant Anim Genome 14: P526.

Wallace DC (1993) Mitochondrial diseases: genotype versus phenotype. Trends Genet 9: 128-133.

Welter C, Dooley S, Blin N (1989) A rapid protocol for the purification of mitochondrial DNA suitable for studying restriction fragment length polymorphism (RFLP). Gene 83: 169-172.

Woychik RP, Camper SA, Lyons RH, Horowitz S, Goodwin EC, Rottman FM (1982) Cloning and nucleotide sequencing of the bovine growth hormone gene. Nucleic Acids Res 10: 7197-7210. 